УДК 615.322:582.734

\title{
СПОСОБ ПОЛУЧЕНИЯ ЛЕКАРСТВЕННОГО РАСТИТЕЛЬНОГО СЫРЬЯ ЛАПЧАТКИ БЕЛОЙ (РОTЕNTILLA ALBA L.) В УСЛОВИЯХ гИдРОПОНИкИ
}

\author{
(C) Л.И. Тихомирова ${ }^{*}$ Н.Г. Базарнова, Т.Н. Ильичёва, А.В. Сысоева \\ Алтайский государственный университет, пр. Ленина, 61, Барнаул, 656049 \\ (Россия), L-tichomirova@yandex.ru
}

Целью данной работы являлась разработка биотехнологического способа получения сырья $P$. alba, сохраняющего групповой химический состав и биологическую активность, сравнимую с интактными растениями. Для получения возобновляемого сырья $P$. alba разработана технология микроклонального размножения и выращивания в условиях гидропоники. Вегетативные почки побегов в весеннее время отделяли от корневища. Стерилизацию проводили в условиях ламинар-бокса $0,1 \%$ раствором сулемы 10 мин. Питательные среды готовили по прописи MS, содержащие 1,0-2,5мкМ БАП. Через 20-30 суток развившиеся побеги пересаживали на среды размножения, содержащие 0,5-1,0 мкМ БАП+0,25-0,5 мкМ ИУК+0,05 мкМ ГК. Укореняли микропобеги на среде МS, дополненной 3 мкМ НУК.

Выращивание растительного сырья осуществляли в питательном растворе на основе жидкой MS, содержащей $1 / 4$ состава макросолей, 1/4 состава микросолей, полный набор витаминов, хелата железа и кальция хлористого. Растительную массу получали при температуре $24-26^{\circ} \mathrm{C}$, режим освещения: 16 ч - день, 8 ч - ночь. При круглогодичном выращивании количество биомассы лекарственного растительного сырья лапчатки белой по данному способу в условиях гидропонной установки «Минивит» составляло 10,05 кг $/ \mathrm{M}^{2}$ по сырой массе за один год.

В экстрактах интактных растений $P$. alba и растений-регенерантов по результатам проведенных качественных реакций идентифицированы флавоноиды, дубильные вещества (гидролизуемые и конденсированные).

Экстракты растений-регенерантов $P$. alba проявляют биологическую активность в отношении вируса герпеса, сравнимую с интактными растениями.

Необходимо продолжить исследования химического состава возобновляемого сырья $P$. alba и определения биологической активности экстрактов в отношении вирусов, наиболее опасных для человека.

Ключевые слова: Potentilla alba L., технология микроклонального размножения, лекарственное растительное сырье, интактные растения, растения-регенеранты, биологическая активность.

\section{Введение}

Potentilla alba L. - многолетнее травянистое растение семейства розоцветных (Rosaceae) произрастает в Европе. Ареал простирается от Центральной Европы до Волги. Северная граница соответствует северу Германии. Этот вид отсутствует в лесах Скандинавии, Финляндии и на Британских островах. Западная граница проходит через Вогезы и Арденны. На юге - через северную часть Италии, Югославии,

Тихомирова Людмила Ивановна - кандидат

биологических наук, заведующая отделом биотехнологии растений ЮСБС АлтГУ, e-mail: L-tichomirova@yandex.ru

Базарнова Наталья Григорьевна - доктор химических наук, профессор, заведующая кафедрой органической химии, декан химического факультета, e-mail: bazarnova@chemwood.asu.ru

Ильичева Татьяна Николаевна - доктор биологических наук, доцент, профессор базовой кафедры АлтГУ «Биоинжиниринга рекомбинантных препаратов», e-mail: L-tichomirova@yandex.ru

Сысоева Александра Викторовна - студентка, e-mail: L-tichomirova@yandex.ru Болгарии, охватывает Европейскую часть России, Украину и Беларусь [1]. Зарослей не образует, встречается рассеянно, часто отдельными экземплярами, не более 2-3 растений на квадратный метр.

Биологически активными составляющими экстракта лапчатки белой являются такие компоненты, как флавоноиды, регулирующие проницаемость и эластичность стенок кровеносных сосудов, предотвращающие атеросклеротические изменения, нейтрализующие свободные радикалы, фенолкарбоновые кислоты, обладающие антимутагенными и

\footnotetext{
* Автор, с которым следует вести переписку.
} 
мочегонными свойствами, и сапонины, гликозиды, имеющие кардиотоническое, нейротропное, гипохолестеринемическое, кортикотропное, адаптогенное и седативное действие [2-5].

Результаты исследований клинической эффективности, проведенные в 1997-2004 гг., позволили получить дополнительные данные относительно широты терапевтического воздействия при различной патологии щитовидной железы и безопасности при длительном применении [6-8].

На основе лапчатки белой выпускают различные препараты и пищевые добавки. Разработано многокомпонентное средство «Тиреотон», в состав которого входят сухие экстракты из корневищ с корнями лапчатки белой (Potentilla alba L.), шлемника байкальского (Scutellaria baicalensis Georgi) и родиолы розовой (Rhodiola rosea L.) [9-11]. В Институте общей и экспериментальной биологии CO РАН (Улан-Удэ) разработан растительный комплексный препарат «Тиреонорм», включающий сухие экстракты корневища лапчатки белой $[12,13]$. Компанией «Эвалар» выпускается растительный комплекс (капсулы и крем) «Эндокринол», который содержит клинически апробированные экстракты лекарственных растений: спиртоводно-глицериновый экстракт лапчатки белой, водный экстракт звездчатки средней, масляный экстракт льнянки обыкновенной для лечения заболеваний щитовидной железы. Помимо этого, на основе экстракта корневищ и корней лапчатки белой выпускаются БАДы «Тирео-Вит», «Нуксен VII», «Лапчатка+» и «Эндонорм», которые рекомендуется использовать при различных заболеваниях щитовидной железы.

Природные лекарственные препараты имеют основной недостаток: ограниченность природных источников, крупномасштабное использование которых влечет за собой вполне определенные экологические проблемы [14]. Поэтому важнейшей задачей для развития фармацевтической и пищевой промышленности, лесного комплекса и смежных отраслей является обеспечение возобновляемым сырьем с необходимыми свойствами. Многолетние исследования доказали высокую эффективность гидропонического производства растений, сопряженного с микроклональным размножением. Независимость от влияния различных факторов окружающей среды (климат, сезон, погода, почвенные условия, вредители), более высокий выход и качество, возможность сертификации продукта делают привлекательной эту технологию для производителей. Производство при четкой организации являет экологически чистым, а продукт (лекарственное сырье) - свободным от гербицидов и тяжелых металлов.

Цель данной работы - разработка биотехнологического способа получения сырья $P$. alba, сохраняющего групповой химический состав и биологическую активность, сравнимую с интактными растениями.

\section{Экспериментальная часть}

Метод культуры ткани. Экспериментальные работы проводили по общепринятым методикам [15, 16]. Растительные ткани культивировали на питательных средах MS (Murashige and Skoog) [17]. Питательные среды дополняли фитогормонами цитокининового типа действия: 6-бензиламинопурином (БАП), кинетином и ауксинового типа действия: индолилмасляной кислотой (ИМК), $\alpha$-нафтилуксусной кислотой (НУК). Также использовали гиббереловую кислоту (ГК).

Для стерилизации эксплантов лапчатки белой использовали хлорсодержащие дезинфицирующие средства. Хорошие результаты получены при использовании $1 \%$ раствора сульфохлорантина в течение 10 мин.

Стерильные экспланты переносили во флаконы с питательной средой. Флаконы закрывали фольгой и помещали в световую климатическую камеру при температуре $+25^{\circ} \mathrm{C}$. Через четыре недели отмечали рост побегов. На этапе собственно микроразмножения использовали следующие среды: №1 - MS+1,0 мкM кинетина, №2 - MS+1,0 мкМ БАП, №3 - MS+ 2,5 мкМ БАП, №4 - MS+1,0 БАП+0,5 ИМК+ 0,05 ГК, №5 MS $+0,5$ БАП+0,25 ИМК $+0,05$ ГК. В качестве контроля готовили безгормональную среду на основе MS.

При введении в культуру in vitro фрагментов цветка для успешной регенерации важным моментом является стадия развития цветков. Необходимо брать нераскрывшиеся цветки среднего размера. Питательную среду готовили на основе MS, дополненной БАП 20,0 мкМ и ИМК 1,0 мкМ.

Растения выращивали в лаборатории при искусственном освещении (2000-4000 лк) в условиях фотопериода: $16 / 8$ часов свет/темнота и температуре $24-26^{\circ} \mathrm{C}$.

Анализ противовирусной активности экстрактов растений-регенерантов P. alba в отнотении виpyca герпесa. Оценку противовирусной активности проводили в государственном научном центре вирусологии и биотехнологии «Вектор». Анализ противовирусной активности in vitro проводили по методу измерения поглощения клетками прижизненного красителя - нейтрального красного (НК) [18]. 
Для оценки противовирусной активности использовали экстракты, извлеченные этанолом (96\%-ным), водой. Работу выполняли на пластиковых планшетах для идентификации и определения чувствительности вирусов к полученным препаратам. Исследование проводилось на рассеянных в планшетах клетках печени собаки. Лунки рядов 10,11, 12 заполняли средой (150 мкл) для контроля клеток и контроля вируса. В остальные лунки добавляли вирус герпеса по 75 мкл и столько же разбавленных экстрактов, перенося их с помощью многоканальной микропипетки. Для изучения влияния одного препарата на вирус герпеса отведено по 2 ряда. Планшеты помещали в $\mathrm{CO}_{2}$ - инкубатор 48 ч.

По истечении 48 ч проводилась оценка активности противогерпесовых препаратов в тесте адсорбции нейтрального красного. Оценка жизнеспособности клеток по адсорбции ими нейтрального красного широко применяется в биомедицинских исследованиях. Метод основан на способности жизнеспособных клеток поглощать и накапливать суправитальный краситель нейтральный красный в лизосомах благодаря электростатическому притяжению. Повреждение лизосомальных мембран приводит к снижению накопления красителя, поэтому интенсивность окрашивания пропорциональна количеству жизнеспособных клеток. Далее измеряли оптическую плотность содержимого лунок на ридере микропланшетном Model 680 при длине волны 490 нм с использованием программы Земфира 2.0.

\section{Обсуждение результатов}

Истощение природных запасов, неблагоприятные изменения климата диктуют необходимость находить новые способы получения лекарственного растительного сырья. Природная сырьевая база $P$. alba крайне незначительна. Растет лапчатка медленно: от прорастания семени до взрослого растения с корневищем длиной 20-30 см проходит не менее 15-20 лет. Велика опасность уничтожения всех имеющихся запасов $P$. alba в природе, если не позаботиться об их восстановлении [19].

Известен способ выращивания лапчатки белой семенами. Недостатком данного способа является низкий процент всхожести семян (менее $10 \%$ ), растянутые сроки прорастания, медленное развитие сеянцев [19]. Крупных плантаций $P$. alba пока не существует. Наиболее продуктивным является способ выращивания черенков лапчатки белой в почвенно-климатических условиях Северного Кавказа [20]. Для массового выращивания лапчатки белой в культуре использовали черенки, полученные при делении материнских растений. На одном месте растения выращивали в течение шести лет. За первый год прирост массы у одно-

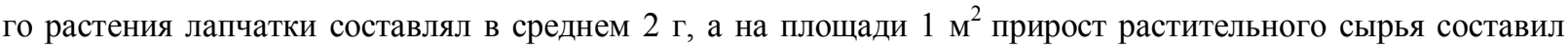
25 г по сырой массе. Недостатками данного способа является малое количество посадочного материала на единице площади и медленный прирост растительной массы.

Разработанный нами способ получения лекарственного растительного сырья лапчатки белой является сопряженным методом клонального микроразмножения и выращиванием в условиях гидропоники.

Микроклональное размножение P. alba. Развитие почек у первичного экспланта (черенков вегетативного побега) зависело от состава питательной среды. При использовании только 2,5 мкМ БАП закладывалась масса почек, но побеги формировались мелкие, что затрудняло дальнейшую работу по разделению и пересадке. Введение в питательные среды ауксина (ИМК) позволило побегам вытянуться, а гиббереловая кислота усиливала данный эффект. Через 20-30 суток развившиеся побеги пересаживали на среды размножения (рис. 1).

Использование почек в качестве эксплантов осложнялось их высокой инфицированностью и низким выходом стерильного материала. Лапчатку белую можно вводить в культуру ткани с помощью фрагментов цветка.

В качестве эксплантов использовали цветоножку и цветоложе. Через 19-25 суток регенерировали полноценные вегетативные побеги. Образовавшиеся почки легко отделялись одна от другой. После пересадки на свежую питательную среду каждая, из них формировала побеги и новые пазушные почки, увеличивая тем самым число точек роста.

При использовании кинетина на среде № 1 формировалось наименьшее количество адвентивных и пазушных побегов. 

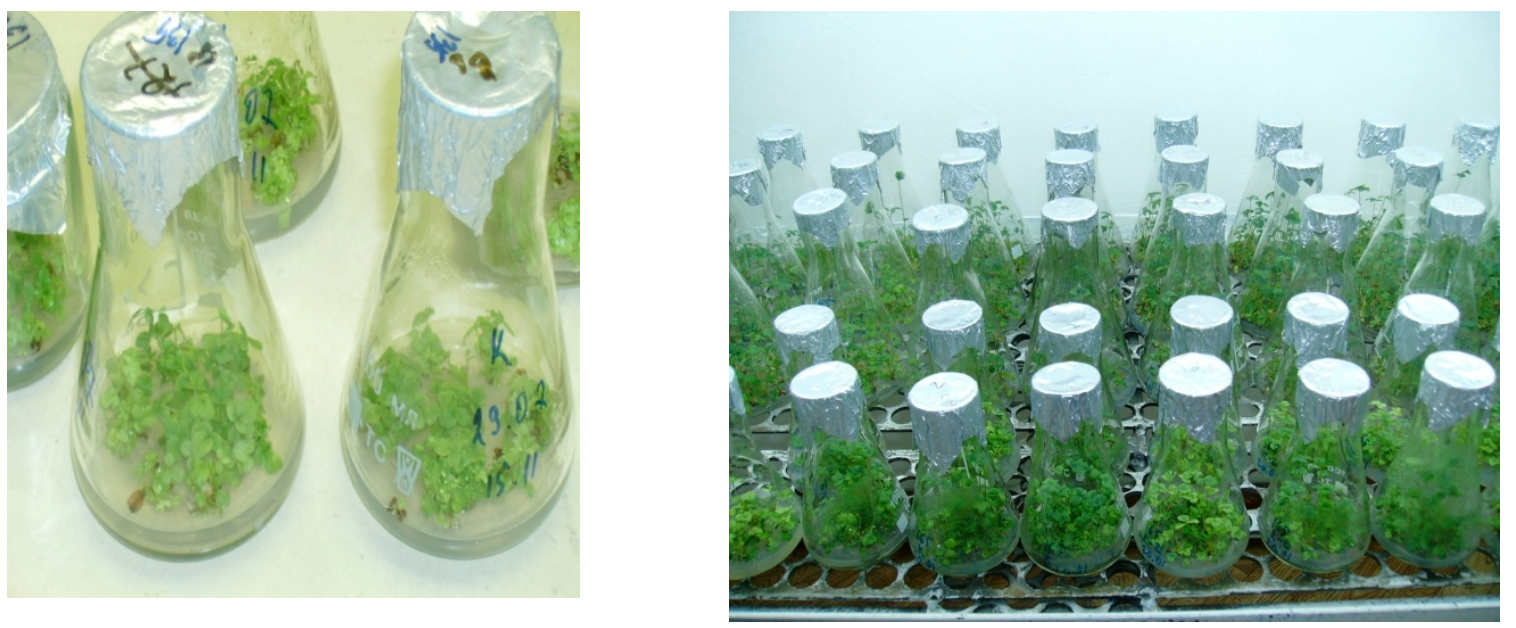

Рис. 1. Этап собственно микроразмножения лапчатки белой

Введение в питательные среды на этапе собственно микроразмножения 1,0-2,5 мкМ БАП индуцировало максимальную регенерацию и развитие пазушных и адвентивных почек у лапчатки белой. У одного побега за один пассаж можно получить в ряде случаев до 20 почек. Но при длительном пассировании на данных средах новообразующиеся побеги имели морфологические изменения, плохо укоренялись, гибли, что, вероятно, связано с накоплением фитогормона в тканях выше необходимого уровня. Для устранения подобного явления необходимо чередовать среды с различной концентрацией фитогормонов.

Оптимальным содержанием фитогормонов для микроразмножения P. alba в культуре in vitro по нашим данным является 1,0 мкМ БАП+0,5 мкМ ИМК+0,05 мкМ ГК (среда №4). Образовавшиеся конгломераты имели хорошее развитие, легко делились на одиночные микропобеги, которые и пересаживали на среды, содержащие 0,5 мкМ БАП+0,25 мкМ ИМК+0,05 мкМ ГК (№5). Число побегов на один эксплант за один пассаж составляло от 3 до 9 штук. Таким образом, чередовали среды каждый пассаж. При этом после среды №5 крупные экземпляры микропобегов высаживали на среды укоренения, а мелкие - на среду №4 для дальнейшего размножения.

Сформированные побеги высотой не менее 20 мм переносили на среду укоренения. Питательная среда содержала 50\% концентрации минеральных солей по прописи MS с добавлением 3 мкМ НУК, 30 г/л сахарозы, 7-9 г/л агара, при рН 5,6-5,8. На 20-24 сутки укоренения побеги лапчатки белой имели корни и достигали стандартных размеров.

На основании теоретического расчета по формуле $\mathrm{Bn}=\mathrm{B} 1 \times \mathrm{G}^{(\mathrm{n}-1)}$ (где $\mathrm{n}-$ количество месяцев культивирования, B1 - количество микропобегов, $\mathrm{G}$ - коэффициент размножения) от одного растения при данном способе культивирования можно получить за 12 месяцев 177147 растений-регенерантов лапчатки белой, если коэффициент размножения равен 3,0 [21]. А применение культуры ткани способствует сокращению материально-трудовых затрат и производственных площадей.

Получение растительного сырья в условиях гидропоники Р. alba. С целью получения растительного лекарственного сырья использовали гидропонную установку типа «Минивит» (А/О «ДОКА» г. Зеленоград, Московская область). Растения-регенеранты вынимали из культуральных сосудов, отмывали корни в дистиллированной воде от агара, закрепляли в кассетах и помещали в установку на 90 суток для адаптации и выращивания растительного сырья. При этом первые 7 суток растения адаптировали к влажности окружающей воздушной среды. Для этих целей растения накрывали полиэтиленовой пленкой, которую через трое суток приоткрывали на короткое время, а затем убирали совсем (рис. 2).

Выращивание лапчатки осуществляли в питательном растворе на основе жидкой MS, содержащей 1/4 состава макросолей, $1 / 4$ состава микросолей, полный набор витаминов, хелата железа и кальция хлористого. Растительную массу получали при температуре $24-26^{\circ} \mathrm{C}$, режим освещения: 16 ч - день, 8 ч - ночь. Сред-

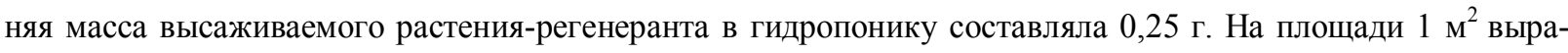
щивали 750 растений. При круглогодичном выращивании количество биомассы лекарственного растительного сырья лапчатки белой по данному способу в условиях гидропонной установки «Минивит» составляло 10,05 кг/м² по сырой массе за один год [22] (рис. 3). 


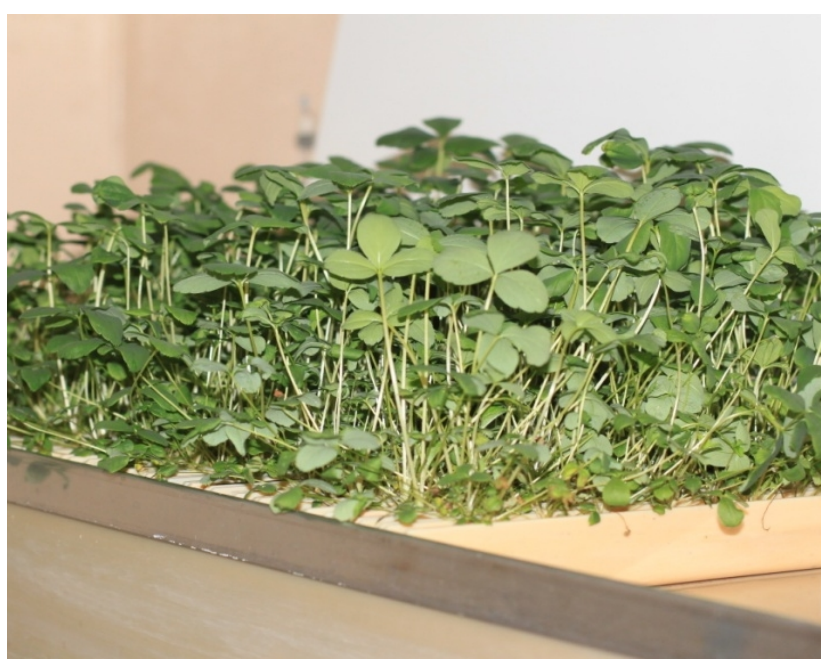

Рис. 2. Получение растительного сырья $P$. alba в условиях гидропоники

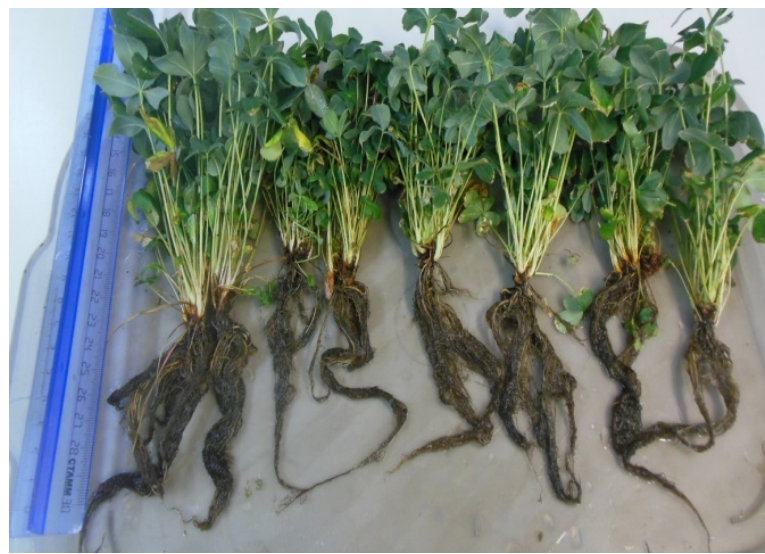

Рис. 3. Растения-регенеранты при выращивании в установке «Минивит» в течение 45 суток.

Сырой вес растения - 10,51 г, вес корней - 3,85 г

Определение группового химического состава и противовирусной активности в отношении вируса простого герпеса экстрактов $P$. alba интактных растений и растений-регенерантов.

Интактные растения $P$. alba, выращенные в полевых условиях в течение трех лет, предоставлены ЗАО «Эвалар».

Экстрактивные вещества извлекали путем последовательной обработки растительного сырья различными растворителями: гексаном, хлороформом, 96\% этанолом, водой. Экстракцию проводили в аппарате Сокслета, обработкой образца в соотношении сырье-экстрагент $1: 10$. Обработку растительного сырья водой проводили выдерживанием образца в растворителе при температуре $60{ }^{\circ} \mathrm{C}$.

Групповой химический состав экстрактивных веществ устанавливали с использованием качественных реакций. При проведении качественной реакции на флавоноиды с раствором гидроксида натрия наблюдали оранжевое окрашивание, что свидетельствует о наличии флавонола, типа кемпферола [23]. При взаимодействии экстракта с хлоридом алюминия выявляли желтое окрашивание, что свидетельствует об образовании комплекса одного из флавоноидных соединений с солью алюминия.

При проведении качественной реакции на дубильные вещества наблюдали выпадение желтого осадка. Это подтверждает наличие конденсированных дубильных веществ, типа катехинов.

В экстрактах интактных растений $P$. alba и растений-регенерантов по результатам проведенных качественных реакций идентифицированы флавоноиды, дубильные вещества (гидролизуемые и конденсированные). Установлено, что интактные растения и растения-регенеранты имеют идентичный групповой состав (табл. 1).

Токсичность экстрактов $P$. alba и их противовирусную активность в отношении вируса простого герпеса исследовали в перевиваемой клеточной культуре почки зеленой мартышки VERO. За пятидесятипроцентную токсичную дозу, $\mathrm{CD}_{50}$, принимали разведение экстракта, при котором погибает 50\% клеток. Пятидесятипроцентная эффективная доза, $\mathrm{ED}_{50},-$ разведение экстракта, которое защищает 50\% клеток от цитопатического действия вируса. Индекс селективности, IS, или терапевтический индекс, - отношение токсичной дозы к эффективной. Результаты представлены в таблице 2.

Таблица 1. Качественное определение биологически активных веществ экстрактов $P$. alba

\begin{tabular}{|c|c|c|c|c|}
\hline \multirow{2}{*}{$\begin{array}{c}\text { Биологически } \\
\text { активные вещества }\end{array}$} & \multirow{2}{*}{ Растворитель } & \multirow{2}{*}{ Реактив } & \multicolumn{2}{|c|}{ Результат реакции } \\
\hline & & & Интактные растения & Растения-регенеранты \\
\hline Флавоноиды & этанол 96\% & $\begin{array}{c}\text { Раствор гидроксида натрия } \\
\text { Водный раствор хлорида } \\
\text { алюминия }\end{array}$ & $\begin{array}{l}+ \\
+\end{array}$ & $\begin{array}{l}+ \\
+\end{array}$ \\
\hline $\begin{array}{l}\text { Дубильные } \\
\text { вещества }\end{array}$ & вода & $\begin{array}{c}\text { Бромная вода } \\
\text { Соль окисного железа }\left(\mathrm{Fe}_{2} \mathrm{O}_{3}\right)\end{array}$ & $\begin{array}{l}+ \\
+\end{array}$ & $\begin{array}{l}+ \\
+\end{array}$ \\
\hline
\end{tabular}


Таблица 2. Токсичность и противовирусная активность экстрактов растительного сырья P. alba, разного способа получения (корни и корневища)

\begin{tabular}{l|c|c|c|c}
\hline Сырье для экстракции & Растворитель & $\begin{array}{c}\text { Токсичность, } \mathrm{CD}_{50} \\
\text { (разведение экс- } \\
\text { тракта) }\end{array}$ & $\begin{array}{c}\text { Противовирусная актив- } \\
\text { ность, } \mathrm{ED}_{50} \text { (разведение } \\
\text { экстракта) }\end{array}$ & $\begin{array}{c}\text { Индекс селек- } \\
\text { тивности, IS }\end{array}$ \\
\hline интактные растения & вода & $1: 120$ & $1: 10240$ & 85 \\
растения-регенеранты & вода & $1: 80$ & $1: 5120$ & 64 \\
интактные растения & $96 \%$ этиловый спирт & $>1: 40$ & $1: 160$ & $>4$ \\
растения-регенеранты & $96 \%$ этиловый спирт & $>1: 40$ & $1: 160$ & $>4$ \\
\hline
\end{tabular}

Как следует из таблицы 2, значительную противовирусную активность проявили водные экстракты P. alba. При невысокой токсичности и интактные растения, и растения-регенеранты имели относительно высокий индекс селективности: 85 и 64 соответственно. Спиртовые экстракты этих растений обладали слабой противовирусной активностью $\left(\mathrm{ED}_{50}\right.$ равен разведению $\left.1: 160\right)$ и, несмотря на слабую токсичность $\left(\mathrm{CD}_{50}>1: 40\right)$, имели очень низкий индекс селективности $(>4)$.

Особо следует отметить, что данные, полученные для интактных растений и растений-регенерантов, сопоставимы: все показатели отличаются не более чем в 2 раза, что не превышает ошибку метода.

\section{Заключение}

Для получения возобновляемого сырья $P$. alba разработана технология микроклонального размножения, сопряженная с выращиванием в условиях гидропроники. Полученный посадочный материал методом микроклонального размножения выращивают в гидропонной установке «Минивит» на питательной среде MS (Мурасига-Скуга), содержащей 1/4 состава макросолей, 1/4 состава микросолей, полный набор витаминов, хелата железа и кальция хлористого, при температуре $24-26{ }^{\circ} \mathrm{C}$, режим освещения: 16 ч - день, 8 ч - ночь, позволяющей получить 10,05 кг/м² лекарственного растительного сырья лапчатки белой по сырой массе за 1 год в условиях круглогодичных теплиц [22].

В экстрактах интактных растений $P$. alba и растений-регенерантов по результатам проведенных качественных реакций идентифицированы флавоноиды, дубильные вещества (гидролизуемые и конденсированные). Установлено, что интактные растения и растения-регенеранты имеют идентичный групповой состав и проявляют сопоставимую биологическую активность в отношении вируса герпеса.

\section{Список литературы}

1. Юрцев Б.А., Камелин Р.В Программы флористических исследований разной степени деятельности // Теоретические и методические проблемы сравнительной флористики. Л., 1987. С. 219-142.

2. Гриценко О.М., Смик Г.К. Фітохімічне досліджения перстачу білого // Фармацевтичний журнал. 1977. №1. C. 88.

3. Рупасова Ж.А., Игнатенко В.А., Василевская Т.И. и др. Сравнительная оценка накопления фенольных соединений в надземных и подземных органах лапчатки в условиях Беларуси // Бюллетень Главного ботанического сада. 2002. Вып. 183. С. 34.

4. Семенова Е.Ф., Преснякова Е.В. Химический состав лапчатки белой и применение ее с лечебной целью // Химия и компьютерное моделирование. Бутлеровские сообщения. 2001. № 5. URL: http://chem.kstu.ru/butlerov_comm/vol2/cd-a2/data/jchem\&cs/russian/n5/1vr103/103.htm

5. Роговский В.С., Матюшин А.И., Шимановский Н.Л. Перспективы применения препаратов кверцетина для профилактики и лечения атеросклероза // Международный медицинский журнал. 2011. Т. 17. №3. С. 114-118.

6. Захария А.В. Исследования лапчатки белой как перспективного средства для лечения заболеваний щитовидной железы : автореф. дис. ... канд. биол. наук. Львов, 1997. 18 с.

7. Каюкова В.А. Эксперимент с лапчаткой белой оправдал надежды // Народный доктор. 2004. №16. С. 15-19.

8. Каминский А.В., Киселёва И.А., Тёплая Е.В. Клинические возможности применения лапчатки белой в профилактике и лечении патологии щитовидной железы // Эндокринология. 2014. №1. С. 45-50.

9. Архипова Э.В. Влияние экстракта Potentilla alba L. и комплексного средства «Тиреотон» на течение экспериментального гипотиреоза : автореф. дис. ... канд. мед. наук. Улан-Удэ, 2012. 21 с.

10. Хобракова В.Б., Архипова Э.В., Водопьянова А.М. Влияние сухого экстракта лапчатки белой на состояние клеточного и гуморального звеньев иммунного ответа // Бюллетень ВСНЦ СО РАМН. 2011. №1 (77). С. 195-197.

11. Хобракова В.Б. Иммунокорригирующее действие сухого экстракта лапчатки белой и комплексного средства «Тиреотон» // Сибирский медицинский журнал. 2011. №7. С. 121-123. 
12. Водопьянова А.В. Влияние «Тиреонорма» на функциональное состояние центральной нервной системы // Бюллетень ВСНЦ СО РАМН. 2011. №1. С. 128-130.

13. Водопьянова А.М. Фармакологическая коррекция тиреотоксикоза комплексным растительным средством «Тиреонорм» : автореф. дис. ... канд. мед. наук. Улан-Удэ, 2012. 20 с.

14. Племенков В.В. Природные соединения - основной базис поиска химиотерапевтических субстанций // Новые достижения в химии и химической технологии растительного сырья : материалы IV Bсероссийской научной конференции. Барнаул, 2009. Т. 2. С. 11-14.

15. Бутенко Р.Г. Биология клеток высших растений in vitro и биотехнология на их основе : учебное пособие. М., 1999. $160 \mathrm{c}$.

16. Вечернина Н.А. Методы биотехнологии в селекции, размножении и сохранении генофонда растений. Барнаул, 2004. $205 \mathrm{c}$.

17. Murashige T., Skoog F. A Revised Medium for Rapi Growth and Bioassaya with Tobacco Tissue cultures // Physiol. Plant. 1962. Vol. 15. N3. Pp. 473-497.

18. Finter N. B. Dye uptake methods for assessing viral cytopathogenicity and their application to interferon assays // J. Gen. Virol. 1969. N5. Pp. 419-427.

19. Смык Г.К. Лапчатка белая // Химия и жизнь. 1982. №3. С. 30-35.

20. Мелик-Гусейнов В.В., Тхамокова Ф.К., Шильников Д.С. Перспективы выращивания лапчатки белой (Potentilla alba L.) на Северном Кавказе // Вестник МГОУ. 2013. №2. C. 49-52.

21. Патент №2525676 (РФ). Способ получения лапчатки белой (Potentilla alba L.) / Л.И. Тихомирова / 2014.

22. Патент №2570623 (РФ). Способ получения лекарственного растительного сырья лапчатки белой (Potentilla alba L) в условиях гидропоники / Л.И. Тихомирова, Н.Г. Базарнова / 2015.

23. Синютина С.Е., Романцова С.В., Савельева В.Ю. Экстракция флавоноидов из растительного сырья и изучение их антиоксидантных свойств // Вестник ТГУ. 2011. Т. 16, вып. 1. С. 345-347.

Поступило в редакииюю 3 апреля 2016 г.

После переработки 6 июня 2016 г.

Tikhomirova L.I. *, Bazarnova N.G., Il'icheva T.N., Sysoeva A.V. PROCESS FOR THE PREPARATION OF MEDICINAL PLANTS OF POTENTILLA ALBA (POTENTILLA ALBA L.) UNDER HYDROPONICS

Altai State University, ul. Lenina, 61, Barnaul, 656049 (Russia), e-mail: L-tichomirova@yandex.ru

The aim of this work was to develop a biotechnological method of producing raw material $P$. alba, preserving the group chemical composition and biological activity comparable to the intact plants. For the production of renewable raw materials $P$. alba developed the technology of micropropagation and cultivation in the conditions of hydroponics. Vegetative buds of shoots in the spring was separated from rhizomes. The sterilization was conducted under the conditions of laminar box $0,1 \%$ solution of mercuric chloride for 10 minutes. Nutrient medium was prepared according to the recipe MS containing of 1,0-2,5 $\mu \mathrm{m}$ BAP. After 20-30 days the developed shoots were transferred to propagation medium containing $0,5-1,0 \mu \mathrm{m}$ BAP $+0,25-0,5$ $\mu \mathrm{m}$ IAA $+0,05$ microns GK. Microdamage were planted on MS medium supplemented with 3 ám NAA.

The cultivation of vegetable raw materials was carried out in a nutrient solution based on liquid MS containing composition macrosoma $1 / 4,1 / 4$ part microsoma, full set of vitamins, chelate iron, and calcium chloride. Vegetative mass was obtained at a temperature of $24-26^{\circ} \mathrm{C}$, light regime: 16 hours day 8 hours night. During year-round cultivation of the biomass of medicinal plants of the white cinquefoil on this method in the conditions of a hydroponic set-up "Minivet" was $10,05 \mathrm{~kg} / \mathrm{m}^{2}$ in wet weight for one year.

In extracts of intact plants of $P$. alba and of regenerated plants according to the results of the qualitative responses identified flavonoids, tannins (hydrolyzable tannins and condensed).

Extracts of regenerated plants of $P$. alba exhibit biological activity against herpes virus is comparable to the intact plants.

It is necessary to continue studies of the chemical composition of renewable raw materials $P$. alba and determining the biological activity of the extracts against the most dangerous viruses to humans.

Keywords: Potentilla alba L., the technology of micropropagation, medicinal plant raw, intact plants, plant regenerants, biological activity.

\footnotetext{
* Corresponding author.
} 


\section{References}

1. Iurtsev B.A., Kamelin R.V. Teoreticheskie i metodicheskie problemy sravnitel'noi floristiki. [Theoretical and methodological problems of comparative floristics]. Leningrad, 1987, pp. 219-142. (in Russ.).

2. Gritsenko O.M., Smik G.K. Farmatsevtichnii zhurnal, 1977, no. 1, pp. 88. (in Russ.).

3. Rupasova Zh.A., Ignatenko V.A., Vasilevskaia T.I. i dr. Biulleten' Glavnogo botanicheskogo sada, 2002, no. 183, p. 34 (in Russ.).

4. Semenova E.F., Presniakova E.V. Khimiia i komp'iuternoe modelirovanie. Butlerovskie soobshcheniia, 2001, no. 5, URL: http://chem.kstu.ru/butlerov_comm/vol2/cd-a2/data/jchem\&cs/russian/n5/1vr103/103.htm. (in Russ.).

5. Rogovskii V.S., Matiushin A.I., Shimanovskii N.L. Mezhdunarodnyi meditsinskii zhurnal, 2011, vol. 17, no. 3, pp. 114-118. (in Russ.).

6. Zakhariia A.V. Issledovaniia lapchatki beloi kak perspektivnogo sredstva dlia lecheniia zabolevanii shchitovid-noi zhelezy: Avtoref. dis. ... kand. biol. nauk. [Research cinquefoil white as a promising agent for the treatment of diseases of the thyroid gland: Author. Dis. ... cand. biol. sciences]. L'vov, 1997, 18 p. (in Russ.).

7. Kaiukova V.A. Narodnyi doktor, 2004, no. 16, pp. 15-19. (in Russ.).

8. Kaminskii A.V., Kiseleva I.A., Teplaia E.V. Endokrinologiia, 2014, no. 1, pp. 45-50. (in Russ.).

9. Arkhipova E.V. Vliianie ekstrakta Potentilla alba L. i kompleksnogo sredstva «Tireoton» na techenie eksperimental'nogo gipotireoza: avtoref. dis. ... kand. med. nauk. [Effect of extract of Potentilla alba L., and comprehensive means "Tireoton" on the course of experimental hypothyroidism: Abstract. Dis. ... Cand. honey. sciences]. Ulan-Ude, 2012, 21 p. (in Russ.).

10. Khobrakova V.B., Arkhipova E.V., Vodop'ianova A.M. Biulleten' VSNTs SO RAMN, 2011, no. 1 (77), pp. $195-197$. (in Russ.).

11. Khobrakova V.B. Sibirskii meditsinskii zhurnal, 2011, no. 7, pp. 121-123. (in Russ.).

12. Vodop'ianova A.V. Biulleten' VSNTS SO RAMN, 2011, no. 1, pp. 128-130. (in Russ.).

13. Vodop'ianova A.M. Farmakologicheskaia korrektsiia tireotoksikoza kompleksnym rastitel'nym sredstvom «Tireonorm»: avtoref. dis. ... kand. med. nauk. [Pharmacological correction of thyrotoxicosis complex herbal remedies "Tireonorm": Author. Dis. ... cand. honey. sciences]. Ulan-Ude, 2012, 20 p. (in Russ.).

14. Plemenkov V.V. Novye dostizheniia $v$ khimii $i$ khimicheskoi tekhnologii rastitel'nogo syr'ia. Materialy IV Vserossiiskoi nauchnoi konferentsii. [New advances in chemistry and chemical technology of vegetable raw materials. Proceedings of the IV All-Russian Scientific Conference]. Barnaul, 2009, vol. 2, pp. 11-14. (in Russ.).

15. Butenko R.G. Biologiia kletok vysshikh rastenii in vitro i biotekhnologiia na ikh osnove: Uchebnoe posobie. [Biology in vitro cells of higher plants and biotechnology based on them: Textbook]. Moscow, 1999, 160 p. (in Russ.).

16. Vechernina H.A. Metody biotekhnologii v selektsii, razmnozhenii i sokhranenii genofonda rastenii. [The methods of biotechnology in plant breeding, reproduction and preservation of the gene pool of plants]. Barnaul, 2004, 205 p. (in Russ.).

17. Murashige T., Skoog F. Physiol. Plant., 1962, vol. 15, no. 3, pp. 473-497.

18. Finter N.B. J. Gen. Virol., 1969, no. 5, pp. 419-427.

19. Smyk G.K. Khimiia i zhizn', 1982, no. 3, pp. 30-35. (in Russ.).

20. Melik-Guseinov V.V., Tkhamokova F.K., Shil'nikov D.S. Vestnik MGOU, 2013, no. 2, pp. 49-52. (in Russ.).

21. Patent 2525676 (RU). 2014. (in Russ.).

22. Patent 2570623 (RU). 2015. (in Russ.).

23. Siniutina S.E., Romantsova S.V., Savel'eva V.Iu. Vestnik TGU, 2011, vol. 16, no. 1, pp. 345-347. (in Russ.).

Received April 3, 2016

Revised June 6, 2016 